\title{
The Functional Characterization of Bat and Human P[3] Rotavirus VP8*s
}

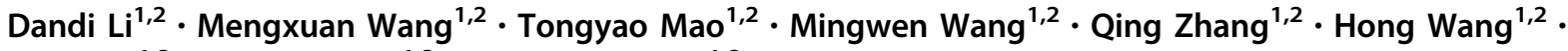 \\ Lili Pang ${ }^{1,2} \cdot$ Xiaoman Sun $^{1,2}$ (1) $\cdot$ Zhaojun Duan $^{1,2}$ (1)
}

Received: 6 January 2021 / Accepted: 12 April 2021 / Published online: 31 May 2021

(C) Wuhan Institute of Virology, CAS 2021

\begin{abstract}
$\mathrm{P}[3]$ rotavirus (RV) has been identified in many species, including human, simian, dog, and bat. Several glycans, including sialic acid, histo-blood group antigens (HBGAs) are reported as RV attachment factors. The glycan binding specificity of different P[3] RV VP8*s were investigated in this study. Human HCR3A and dog P[3] RV VP8*s recognized glycans with terminal sialic acid and hemagglutinated the red blood cells, while bat P[3] VP8* showed neither binding to glycans nor hemagglutination. However, the bat P[3] VP8* mutant of $\mathrm{C} 189 \mathrm{Y}$ obtained the ability to hemagglutinate the red blood cells, while human P[3] HCR3A/M2-102 mutants of Y189C lost the ability. Sequence alignment and structural analysis indicated that residue 189 played an important role in the ligand recognition and may contribute to the cross-species transmission. Structural superimposition exhibited that bat P[3] VP8* model was quite different from the simian P[3] Rhesus rotavirus (RRV) P[3] VP8*, indicating that bat P[3] RV was relatively distinct and partially contributed to the no binding to tested glycans. These results promote our understanding of P[3] VP8*/glycans interactions and the potential transmission of bat/ human P[3] RVs, offering more insight into the RV infection and prevalence.
\end{abstract}

Keywords Bat rotavirus $\cdot \mathrm{P}[3] \mathrm{VP} 8^{*} \cdot$ Glycan binding specificity $\cdot$ Hemagglutination $\cdot$ Sialic acid

\section{Introduction}

Rotavirus (RV) is a major pathogen leading to the acute viral gastroenteritis in young children and animals. RV genome contains 11 double stranded RNA fragments, encoding 12 proteins, including 6 structural and 6 nonstructural proteins (Estes 2013). Based on VP6, RVs can be divided into ten different species by now, including A-H, one tentative species I, and a candidate species J (Banyai et al. 2017). The RV particle consists of three capsid layers. Two major surface proteins, VP7 and VP4, formed the

Dandi Li and Mengxuan Wang have contributed equally to this work.

Xiaoman Sun

sunxiaoman88@163.com

$\triangle$ Zhaojun Duan

zhaojund@126.com

1 National Health Commission Key Laboratory for Medical Virology and Viral Diseases, Beijing 102206, China

2 National Institute for Viral Disease Control and Prevention, China CDC, Beijing 102206, China outer most layer and played an important role in inducing neutralizing antibodies and protective immunity. VP7 and VP4 defined the RV G and P genotypes, respectively (Matthijnssens et al. 2011). The group A RVs are diverse and has been identified $51 \mathrm{P}$ genotypes so far (https://rega. kuleuven.be/cev/viralmetagenomics/virus-classification/ 7th-RCWG-meeting). VP4 can be cleaved by trypsin into two fragments, VP5* and VP8* (Fiore et al.. 1991). VP8* located at the distal part of the VP4 spike and was reported to be essential in the glycan recognition and cell attachment (Dormitzer et al. 2002a).

RVs were identified in many species, including human, porcine, bovine, dog and birds. Bats, the reservoirs of many viruses, were also identified to harbor the RVs (He et al. 2013). The genetic analysis of bat RVs indicated the bat-tohuman transmission and reassortment (He et al. 2017; Komoto et al. 2020). The cross-species transmission of $\mathrm{RVs}$ has been reported in several RV genotypes, including $\mathrm{P}[6], \mathrm{P}[3] \mathrm{RVs}$ that were reported in both human and animal infections (Nyaga et al. 2018; Okitsu et al. 2018). $\mathrm{P}[3] \mathrm{RVs}$ were identified in various species, including human, simian, dog, and bat (Tsugawa and Hoshino 2008; 
He et al. 2013; Sasaki et al. 2016). Bat P[3] LZHP2 was identified in an insectivorous bat and shared high nucleotide identity with the unique human strain M2-102 that was suggested to originate from a bat RV as a result of crossspecies transmission and was divergent from other human RV strains (Dong et al. 2016; He et al. 2017). Human HCR3A was supposed to be of dog origin (Tsugawa and Hoshino 2008). The molecular mechanism of the prevalence of these $\mathrm{P}[3] \mathrm{RV}$ s remained elusive.

Attachment to the cell receptors is crucial for the virus infection and transmission. The illustration of the interactions between virus and ligand provided the basis for understanding host tropism, host adaptation, and zoonosis. Previous studies have shown that some animal RVs recognize sialic acid-containing glycoconjugates and are neuraminidase sensitive (Ciarlet and Estes 1999; Isa et al. 2006). Some animal RV VP8*s, including P[1] bovine Nebraska calf diarrhea virus, $\mathrm{P}[2]$ simian SA11, $\mathrm{P}$ [7] porcine CRW-8 were reported to interact with terminal sialic acids on the cell surface glycans (Ciarlet and Estes 1999). The simian P[3] Rhesus rotavirus (RRV) VP8* recognized N-acetylneuraminic acid (Neu5Ac) and the crystal structure of RRV VP8* in complex with Neu5Ac has also been determined (Dormitzer et al. 2002b). The glycan binding site located at one corner of the two beta-sheets. CRW-8 P[7] VP8* was found to bind the sialic acid using the same glycan binding site as that of RRV P[3] (Blanchard et al. 2007).

Though the interaction between RRV P[3] and sialic acid has been reported, the glycan binding specificities of the $\mathrm{P}[3] \mathrm{RV}$ s of other species is not clear yet, especially the bat P[3] RVs. Here, the functional features of bat, human, and $\operatorname{dog} \mathrm{P}[3] \mathrm{RVs}$ were investigated, which deepened the understanding of $\mathrm{P}[3] \mathrm{RV}$ prevalence and transmission from animals to human.

\section{Materials and Methods}

\section{Protein Expression and Purification}

The full VP8* fragments (residues 1-231 amino acids) of human HCR3A (Genebank: EU708904), 12,638 (Genebank: LC340022), M2-102 (Genebank: KU597745), dog RV19895 (Genebank: HQ661137), and bat LZHP2 (Genebank: KX814943) were synthesized by Genewiz company (Suzhou, China) and cloned into pGEX6P-1 with an N-terminal GST tag. The GST-fusion proteins were expressed in E.coli and induced with isopropyl- $\beta$-D-thiogalactopyranoside (IPTG) at a final concentration of $0.4 \mathrm{mmol} / \mathrm{L}$ at $22{ }^{\circ} \mathrm{C}$ for $16 \mathrm{~h}$. The recombinant proteins were purified as previously reported (Ma et al. 2015; Sun et al. 2018). Briefly, the bacteria were collected and resuspended, followed by ultrasonication. The supernatant of the bacterial lysates was filtered through a $0.22 \mu \mathrm{m}$ membrane (Millipore) and then loaded onto the glutathione sepharose (GE Healthcare Life Sciences). The column was washed with PBS five times. Then the protein of interest was eluted with buffer of $50 \mathrm{mmol} / \mathrm{L}$ Tris- $\mathrm{HCl}, 10 \mathrm{mmol} / \mathrm{L}$ reduced glutathione, $\mathrm{pH}$ 8.0. The eluted proteins were concentrated and the buffer was changed to PBS. The protein concentration was determined using the BCA kit (BD Biosciences). Bat $\mathrm{P}[3]$ mutant of C189Y and human M2-102/HCR3A mutant of Y189C were cloned using the site-directed point mutation. The mutant proteins were expressed and purified as described above. The eluted proteins were analyzed by sodium dodecyl sulfate-polyacrylamide gel electrophoresis (SDS-PAGE).

\section{Oligosaccharide Binding Assay}

Enzyme-linked immunosorbent assay (ELISA)-based oligosaccharide binding assays were conducted as previously described (Sun et al. 2020). The GST-VP8* fusion proteins were coated onto microtiter plates at $20 \mu \mathrm{g}$ per well with incubation at $4{ }^{\circ} \mathrm{C}$ overnight. Following blockage with $5 \%$ nonfat milk, synthetic oligosaccharides conjugated with polyacrylamide (PAA) and biotin were added at $0.2 \mu \mathrm{g}$ per well. The following oligosaccharides were used in this study: Neu5Ac, Neu5Gc, Neu5Aca2-3Gal, Neu5Aca2-6Gal, siaLea, siaLex, siaLec, Neu5Aca23Gal $\beta 1-4 G l c N A c$ (3'SLN), A/B disaccharides, H1, H2, lea, lex, leb, ley, mucin core 1-mucin core 6 , and core 8 (GlycoTech, USA). Then, horseradish peroxidase (HRP)conjugated streptavidin (Abcam) was added at $0.1 \mu \mathrm{g}$ per well. For each step, the plates were incubated at $37^{\circ} \mathrm{C}$ for $1 \mathrm{~h}$, and washed five times with $0.5 \%$ PBS-Tween 20 buffer between steps. The color reactions were developed using a 3,3',5,5'-tetramethylbenzidine (TMB) kit (BD Biosciences). The absorbance of $450 \mathrm{~nm}$ was measured.

\section{Glycan Microarray Screening Analysis}

Glycan ligand screening for human M2-102 and bat LZHP2 P[3] VP8*-GST fusion proteins were performed by the Protein-Glycan Interaction Core of the Consortium for Functional Glycomics (CFG) (http://www.functionalgly comics.org/) against a library containing 600 glycans. The identities of all glycans in Version 5.3 of the array are available at http://www.functionalglycomics.org/static/con sortium/resources/resourcecoreh8.shtml. The recombinant GST-VP8* protein was used at protein concentrations of $5 \mu \mathrm{g} / \mathrm{mL}$ and $50 \mu \mathrm{g} / \mathrm{mL}$, respectively. The bound GSTVP8* proteins were detected using a fluorescence-labeled anti-GST monoclonal antibody (Sigma). Fluorescence was measured and quantified by a microarray scanner and relative fluorescent unit (RFU) for binding to each glycan was calculated (Cholleti et al. 2012). 


\section{Biolayer Interometry (BLI) Analysis}

The interactions between P[3] VP8*s and different oligosaccharides were further analyzed using Octet RED96 (ForteBio., USA). Oligosaccharides with PAA-biotin tag $(10 \mu \mathrm{g} / \mathrm{mL}) \quad$ (Neu5Ac, Neu5Gc, Neu5Ac $\alpha 2-3 \mathrm{Gal} \beta 1-$ 4GlcNA(3'SLN), Neu5Ac $\alpha 2-6 \mathrm{Gal}, \mathrm{H} 1, \mathrm{H} 2$, H3, Neu5Ac $\beta 2-$ 6(Galß1-3)GalNAc, B disaccharide, A disaccharide, B tetrasaccharide, core1, core2, core8, siaLea, siaLex, siaLec, lea, leb, lex, ley) were immobilized on the streptavidinbiosensor. The P[3] VP8* proteins (human HCR3A, M2102, bat LZHP2) were diluted at $10 \mu \mathrm{mol} / \mathrm{L}$ with PBST buffer (PBS with $0.02 \%$ Tween-20, $0.5 \%$ BSA) and added to the 96-well microplate. The VP8* proteins were injected and binding responses were measured. The apparent equilibrium dissociation constants for VP8* and oligosaccharides were calculated using Octet analyzing software.

\section{Hemagglutination}

The GST-VP8* proteins were twofold serially diluted with a starting concentration of $2 \mathrm{mg} / \mathrm{mL}$ using PBS buffer and added to 96-well V-bottom plates (Costar) with $50 \mu \mathrm{L}$ per well. Animal red blood cells (RBCs) (Gelaidisi, Beijing) of porcine, rabbit, bovine, chicken, lamb, and human RBCs (A, B, O types, donated by lab colleagues) were diluted to $1 \%$ with PBS. Written informed consents were signed by the colleagues. Authorization for the sampling of human and animal blood was obtained. Then $50 \mu \mathrm{L}$ of $\mathrm{RBC}$ was added to each well. Agglutination was determined after incubation at $25^{\circ} \mathrm{C}$ for $1 \mathrm{~h}$.

\section{Homology Modeling and Structural Analysis}

A homology model of bat P[3] VP8* was constructed based on the structure of RRV P[3]VP8* (PDB identifier [ID] $1 \mathrm{KQR}$ ) by SWISS-MODEL automated protein structure homology modeling server (http://swissmodel.expasy.org/). The structural superimposition and analysis were performed using pymol (https://pymol.org/2/). The cartoon and surface models of VP8* were shown. The electrostatic potential presentation was calculated with the pymol software.

\section{Results}

\section{VP8* Protein Expression and Purification}

P[3] VP8*s of human (HCR3A, 12,638, M2-102), dog (RV198-95), and bat (LZHP2) were expressed in a soluble form with an N-terminal GST tag. The GST-VP8* proteins were purified via affinity chromatography and the molecular weight were about $52 \mathrm{kDa}$ with free GST protein of $26 \mathrm{kDa}$ (Fig. 1).

\section{P[3] VP8*s Recognized Glycans with Different Patterns}

VP8* proteins were applied to the ELISA to investigate the binding to synthetic oligosaccharides. Human HCR3A, 12,638, and dog RV198-95 P[3] VP8*s exhibited binding to glycans with sialic acid, such as Neu5Aca2-3Gal, Neu5Aco26Gal, and 3'SLN (Fig. 2). Human M2-102 and bat LZHP2 P[3] VP8*s showed no observed binding to the tested glycans.

According to the glycan microarray assay, human M2102 and bat LZHP2 P[3] VP8* exhibited no specific binding to the tested 600 glycans including glycans with sialic acid (Fig. 3). Relative Fluorescent Units (RFUs) indicated the binding intensity. The Human M2-102 and bat LZHP2 P[3] VP8* did not showed high RFU value to these glycans (Fig. 3). For the glycan 117, the RFUs were almost the same for different concentrations and different kinds of proteins. It is suggested that the binding is regarded to be non-specific.

To test the interactions between P[3] VP8*s and different glycans, the biolayer interferometry (BLI) assay was performed using the Octet RED96. The results showed that human HCR3A VP8* specifically recognized glycans with sialic acid, including Neu5Ac, 3'SLN, Neu5Aca2-6Gal, siaLec, siaLea, siaLex (Fig. 4), while P[3] VP8*s of human M2-102 and bat LZHP2 did not recognize any tested glycans.

\section{Hemagglutination of P[3] VP8*s and Mutants}

Hemagglutination was performed to explore the interaction between VP8* and the red blood cells. Human

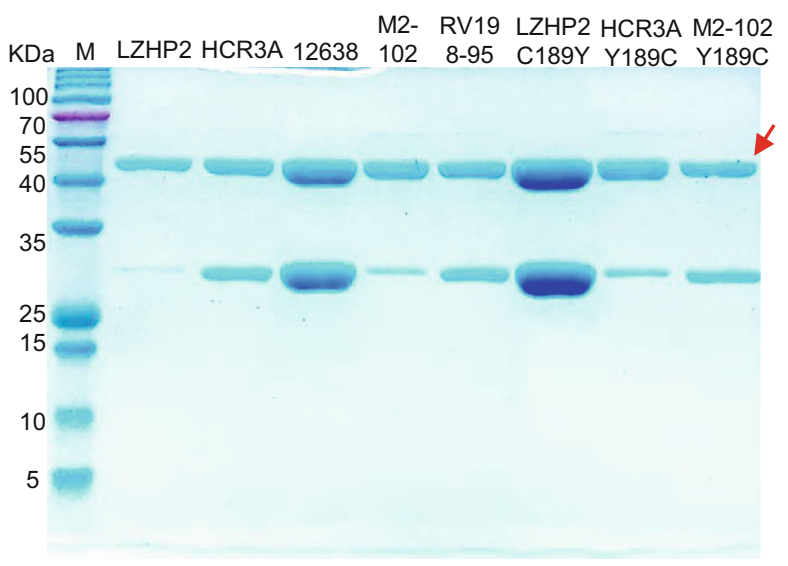

Fig. 1 SDS-PAGE of bat LZHP2 P[3], human HCR3A, 12,638, M2$102 \mathrm{P}[3]$, dog RV198-95 P[3], bat P[3] LZHP2 C189Y, human HCR3A Y189C, human M2-102 Y189C VP8* proteins. The molecular weight of GST-VP8* protein is $\sim 52 \mathrm{kDa}$. The $26 \mathrm{kDa}$ band indicates the free GST protein. The red arrow refers to the protein of interest. 


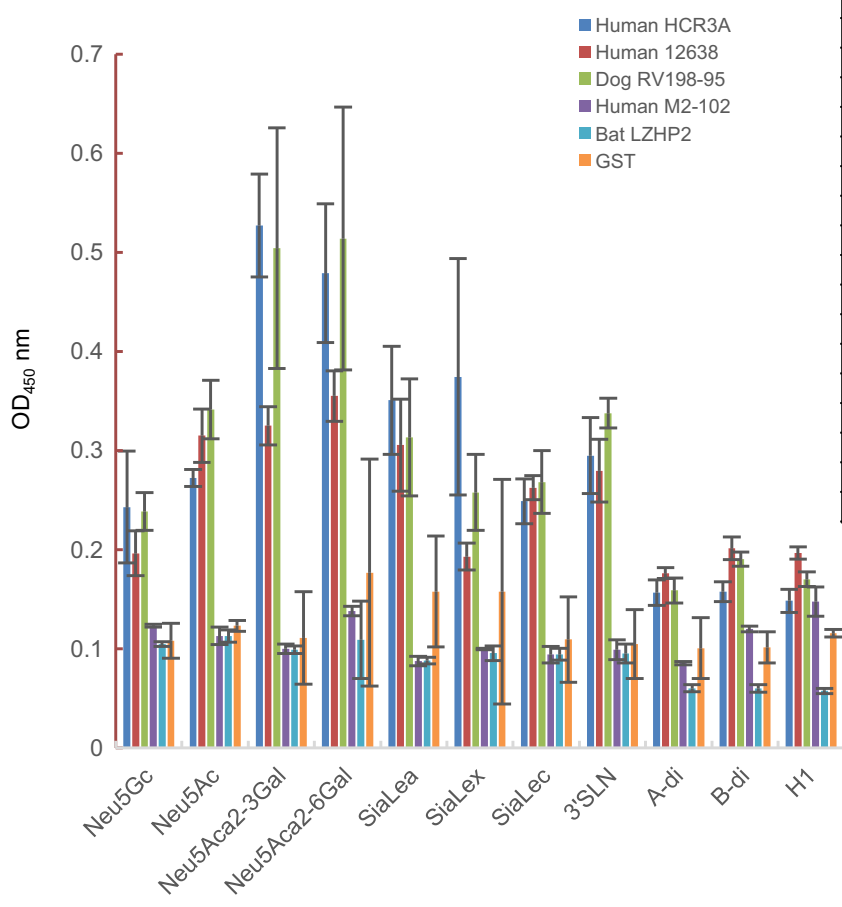

Fig. 2 The glycan binding specificities of P[3] RV VP8*s. PAAbiotin oligosaccharides such as Neu5Ac, Neu5Gc, Neu5Aca2-3Gal, Neu5Ac $\alpha 2-6 \mathrm{Gal}$, siaLea, siaLex, siaLec, Neu5Ac $\alpha 2-3 \mathrm{Gal} \beta 1-$

HCR3A,12,638, M2-102, and dog RV198-95 P[3] VP8*s hemagglutinated the red blood cells of porcine, chicken, rabbit, bovine, lamb, human A, B, O types (Fig. 5). But bat LZHP2 P[3] VP8*s did not hemagglutinate any cells.

It is noted that the VP8*s with Y189 could hemagglutinate the red blood cells. In order to test the function of residue 189, we constructed the mutants of bat LZHP2 P[3] C189Y, human HCR3A Y189C and M2-102 Y189C. Bat $\mathrm{P}[3] \mathrm{C} 189 \mathrm{Y}$ could hemagglutinate the red blood cells, whereas human HCR3A P[3] Y189C and M2-102 Y189C showed no hemagglutination (Fig. 5).

\section{Sequence Alignment of P[3] VP8*s of Different Origins}

Sequence alignment showed that bat LZHP2 P[3] VP8*s possessed various amino acids with the sequence identity of $84.4 \%, 84.4 \%, 97.4 \%, 84.0 \%$ compared to VP8*s of human HCR3A, 12,638, M2-102, dog RV198-95 P[3], respectively. The residues involved in the glycan binding were diverse, especially residue 189 that was essential for the sialic acid binding (Dormitzer et al. 2002b). Bat LZHP2 P[3] VP8* possessed 189 cysteine (C189), while

\begin{tabular}{|c|c|}
\hline Glycans & Molecular Formula \\
\hline Neu $5 A c$ & $\alpha$-Neu 5 Ac $\beta$-PAA -biotin \\
\hline Neu $5 \mathrm{Gc}$ & $\alpha$-Neu $5 \mathrm{Gc} \beta$-PAA -biotin \\
\hline Neu 5 Aca $2-3 \mathrm{Gal}$ & Neu 5 Aca $2-3$ Gal $\beta$-PAA -biotin \\
\hline Neu 5Aca 2-6 Gal & Neu 5Aca 2-6 Gal $\beta$-PAA -biotin \\
\hline SiaLea & 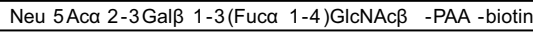 \\
\hline SiaLex & Neu 5 Aca 2-3Gal $\beta$ 1-4 (Fuca 1-3)GIcNAc $\beta$-PAA -biotin \\
\hline SiaLec & Gal $\beta$ 1-3GIcNAc $\beta$-PAA -biotin \\
\hline 3'SLN & Neu 5 Aca 2-3Galß 1-4GlcNAB -PAA -biotin \\
\hline A-di & GalNAca $1-3$ Gal $\beta$-PAA -biotin \\
\hline B-di & Gala 1-3Galß -PAA -biotin \\
\hline $\mathrm{H} 1$ & Fuca 1-2Gal $\beta$ 1-3GIcNAc $\beta$-PAA -biotin \\
\hline $\mathrm{H} 2$ & 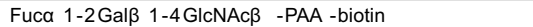 \\
\hline Lea & Galß 1-3(Fuca 1-4)GlcNAcß -PAA -biotin \\
\hline Leb & Fuca 1-2Gal $\beta$ 1-3(Fuca 1-4)GlcNAc $\beta$-PAA -biotin \\
\hline Lex & Gal $\beta$ 1-4(Fuca 1-3)GlcNAc $\beta$-PAA -biotin \\
\hline Ley & Fuca 1-2 Gal $\beta$ 1-4(Fuca 1-3)GlcNAc $\beta$-PAA -biotin \\
\hline Core 1 & Galß 1-3GalNAca -PAA -biotin \\
\hline Core 2 & Galß 1-3(GIcNAcß 1-6)GalNAca -PAA -biotin \\
\hline Core 3 & GIcNAc $\beta$ 1-3GalNAca -PAA -biotin \\
\hline Core 4 & 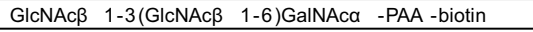 \\
\hline Core 5 & GalNAca 1-3GalNAca -PAA -biotin \\
\hline Core 6 & GIcNAcB $1-6$ GalNAca -PAA -biotin \\
\hline Core 8 & Gald 1-3GalNAca -PAA -biotin \\
\hline
\end{tabular}

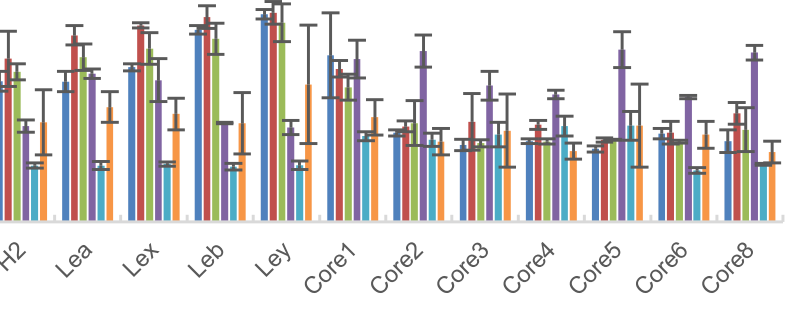

4GlcNAc (3'SLN), Neu5Ac $\beta 2-6(\mathrm{Gal} \beta 1-3)$ GalNAc were included. The absorption at $\mathrm{OD}_{450} \mathrm{~nm}$ was detected. The molecular formula of these glycans were listed in the table.

all the other tested P[3] VP8*s had tyrosine (Y189) (Fig. 6). V144 and T191 in bat LZHP2 P[3] VP8* are the same as that of bat-origin human M2-102, while human HCR3A, 12,638, and dog RV 198-95 P[3] VP8*s possessed S144 and A191. Residues R101, T146, Y155, G187, Y188, S190 are relatively conserved in all these P[3] VP8*s except H155 in human HCR3A.

\section{Structural Analysis of the Glycan Binding Site of P[3] VP8*s}

The homology model of bat P[3] VP8* was constructed based on the P[3] RRV crystal structure ( PDB ID: 1KQR) by SWISS-MODEL. The structural superimposition showed that bat P[3] VP8* model presented typical galectin-like conformation, but it is quite different to RRV $\mathrm{P}[3] \mathrm{VP}{ }^{*}$ with the root mean square deviations (RMSD) values of 1.256 (Fig. 7A). Y189 in RRV P[3] formed hydrogen bonds with sialic acid, while $\mathrm{C} 189$ would lost the interaction (Fig. 7A), which may affect the ligand recognition. V144 and T191 may influence the interactions via the loop conformation, which still need further study to clarify. The surface presentation exhibited that the putative 


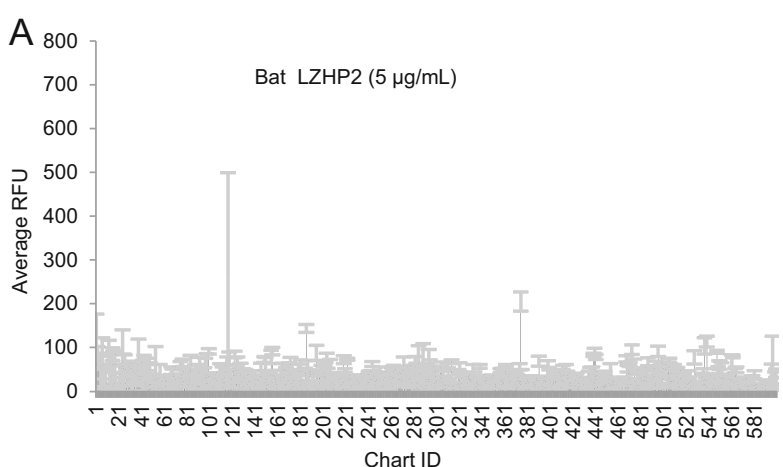

\begin{tabular}{|c|c|c|c|}
\hline $\begin{array}{l}\text { Chart } \\
\text { ID }\end{array}$ & Bat LZHP2 $(5 \mu \mathrm{g} / \mathrm{mL})$ & $\begin{array}{l}\text { Average } \\
\text { RFU }\end{array}$ & StDev \\
\hline 117 & Gala1-3Galb1-4Glc-Sp10 & 257 & 242 \\
\hline 375 & $\begin{array}{l}\text { GalNAcb1-4GIcNAcb1-2Mana1-6(GalNAcb1- } \\
\text { 4GIcNAcb1-2Mana1-3)Manb1-4GIcNAcb1-4GIcNAc- } \\
\text { Sp12 }\end{array}$ & 205 & 22 \\
\hline 186 & GIcNAcb1-4-MDPLys & 144 & 9 \\
\hline 1 & Gala-Sp8 & 114 & 62 \\
\hline 539 & $\begin{array}{l}\text { Galb1-4GIcNAcb1-3Galb1-4GIcNAcb1-3Galb1- } \\
\text { 4GIcNAcb1-2Mana1-6(Galb1-4GIcNAcb1-3Galb1- } \\
\text { 4GIcNAcb1-3Galb1-4GIcNAcb1-2Mana1-3)Manb1- } \\
\text { 4GIcNAcb1-4GIcNAcb-Sp12 }\end{array}$ & 114 & 12 \\
\hline 537 & $\begin{array}{l}\text { GlcNAcb1-3Galb1-4GlcNAcb1-3Galb1-4GlcNAcb1- } \\
\text { 2Mana1-6(GlcNAcb1-3Galb1-4GlcNAcb1-3Galb1- } \\
\text { 4GIcNAcb1-2Mana1-3)Manb1-4GIcNAcb1-4GIcNAcb- } \\
\text { Sp12 }\end{array}$ & 104 & 19 \\
\hline 473 & Neu5Aca2-3Galb1-4GIcNAcb1-2Mana-Sp0 & 95 & 11 \\
\hline 156 & Galb1-4(6S)GIcb-Sp8 & 92 & 8 \\
\hline 440 & (6S)Galb1-3(6S)GIcNAc-Sp0 & 92 & 7 \\
\hline
\end{tabular}

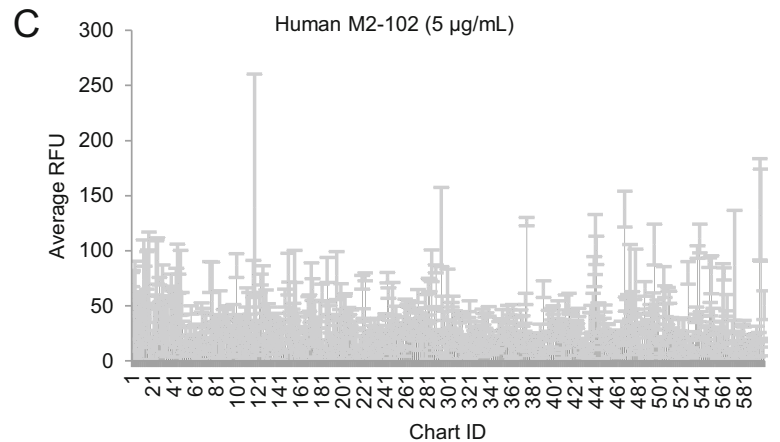

\begin{tabular}{|c|c|c|c|c|}
\hline $\begin{array}{c}\text { Chart } \\
\text { ID }\end{array}$ & human M2-102 (5 $\mu \mathrm{g} / \mathrm{mL})$ & $\begin{array}{l}\text { Average } \\
\text { RFU }\end{array}$ & StDev & $\begin{array}{l}\% \\
\mathrm{CV}\end{array}$ \\
\hline 117 & Gala1-3Galb1-4Glc-Sp10 & 13 & 121 & 87 \\
\hline 468 & $\begin{array}{l}\text { Fuca1-2Galb1-4(Fuca1-3)GlcNAcb1-2Mana1-6(Fuca1- } \\
\text { 2Galb1-4(Fuca1-3)GlcNAcb1-2Mana1-3)Manb1- } \\
\text { 4GIcNAcb1-4(Fuca1-6)GIcNAcb-Sp24 }\end{array}$ & 138 & 16 & 12 \\
\hline 596 & $\begin{array}{l}\text { Neu5Aca2-6Galb1-4GIcNAcb1-3Galb1-4GIcNAcb1- } \\
\text { 3Galb1-4GIcNAcb1-2Mana1-6(Neu5Aca2-6Galb1- } \\
\text { 4GIcNAcb1-3Galb1-4GIcNAcb1-3Galb1-4GIcNAcb1- } \\
\text { 2Mana1-3)Manb1-4GIcNAcb1-4GIcNAcb-Sp12 }\end{array}$ & 138 & 46 & 33 \\
\hline 597 & $\begin{array}{l}\text { Neu5Aca2-3Galb1-4GIcNAcb1-3Galb1-4GIcNAcb1- } \\
\text { 3Galb1-4GIcNAcb1-2Mana1-6(Neu5Aca2-3Galb1- } \\
\text { 4GlcNAcb1-3Galb1-4GIcNAcb1-3Galb1-4GIcNAcb1- } \\
\text { 2Mana1-3)Manb1-4GIcNAcb1-4GIcNAcb-Sp12 }\end{array}$ & 132 & 42 & 32 \\
\hline 375 & $\begin{array}{l}\text { GalNAcb1-4GIcNAcb1-2Mana1-6(GalNAcb1- } \\
\text { 4GIcNAcb1-2Mana1-3)Manb1-4GIcNAcb1-4GIcNAc- } \\
\text { Sp12 }\end{array}$ & 127 & 4 & 3 \\
\hline 294 & 4S(3S)Galb1-4GlcNAcb-Sp0 & 122 & 36 & 30 \\
\hline 539 & $\begin{array}{l}\text { Galb1-4GIcNAcb1-3Galb1-4GlcNAcb1-3Galb1- } \\
\text { 4GIcNAcb1-2Mana1-6(Galb1-4GIcNAcb1-3Galb1- } \\
\text { 4GIcNAcb1-3Galb1-4GIcNAcb1-2Mana1-3)Manb1- } \\
\text { 4GIcNAcb1-4GlcNAcb-Sp12 }\end{array}$ & 111 & 13 & 12 \\
\hline 440 & (6S)Galb1-3(6S)GIcNAc-Sp0 & 106 & 27 & 26 \\
\hline 496 & Fuca1-2(6S)Galb1-3(6S)GlcNAcb-Sp0 & 106 & 19 & 18 \\
\hline 441 & $\begin{array}{l}\text { Fuca1-2Galb1-4 GlcNAcb1-2Mana1-6(Fuca1-2Galb1- } \\
\text { 4GIcNAcb1-2(Fuca1-2Galb1-4GIcNAcb1-4)Mana1- } \\
\text { 3)Manb1-4GIcNAcb1-4GIcNAcb-Sp12 }\end{array}$ & 100 & 13 & 13 \\
\hline
\end{tabular}

B

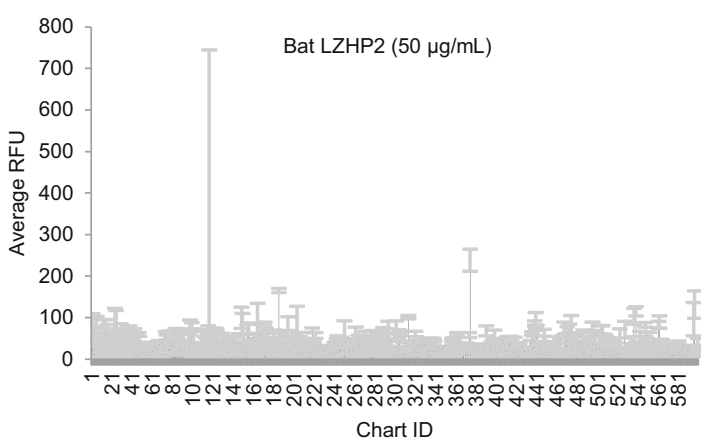

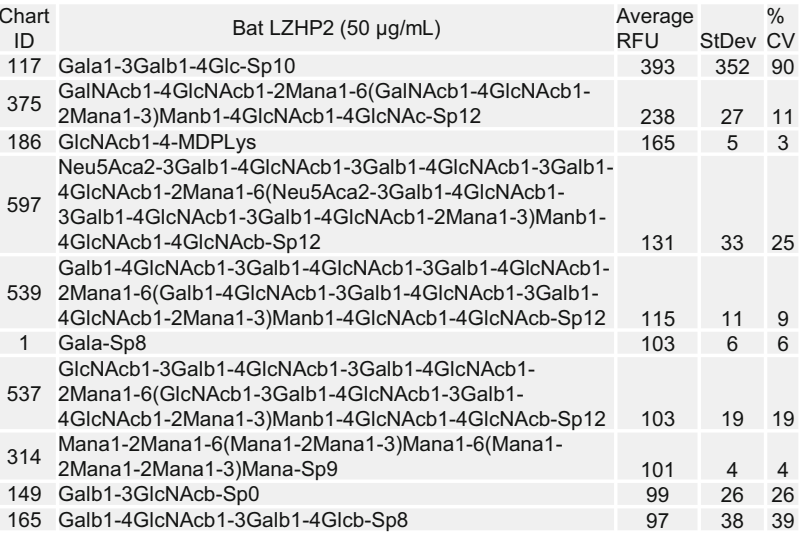

D $300 \quad$ Human M2-102 $(50 \mu \mathrm{g} / \mathrm{mL})$

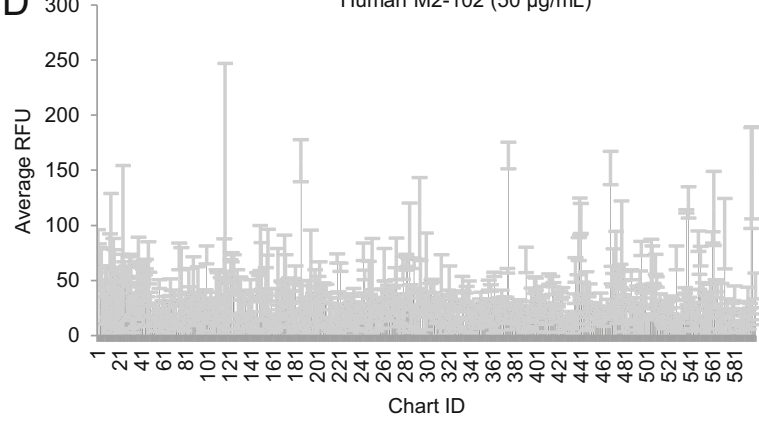

\begin{tabular}{|c|c|c|c|c|}
\hline & Human M2-102 (50 $\mu \mathrm{g} / \mathrm{mL})$ & Average & & \\
\hline & & & & \\
\hline 375 & $\begin{array}{l}\text { GalNAcb1-4GIcNAcb1-2Mana1-6(GalNAcb1-4GIcNAcb1- } \\
\text { 2Mana1-3)Manb1-4GIcNAcb1-4GlcNAc-Sp12 }\end{array}$ & 163 & 12 & 7 \\
\hline 186 & GlcNAcb1-4-MDPLys & 159 & 19 & 12 \\
\hline 468 & $\begin{array}{l}\text { Fuca1-2Galb1-4(Fuca1-3)GIcNAcb1-2Mana1-6(Fuca1- } \\
\text { 2Galb1-4(Fuca1-3)GIcNAcb1-2Mana1-3)Manb1- } \\
\text { 4GIcNAcb1-4(Fuca1-6)GIcNAcb-Sp24 }\end{array}$ & 152 & 15 & 10 \\
\hline 597 & $\begin{array}{l}\text { Neu5Aca2-3Galb1-4GlcNAcb1-3Galb1-4GIcNAcb1- } \\
\text { 3Galb1-4GIcNAcb1-2Mana1-6(Neu5Aca2-3Galb1- } \\
\text { 4GIcNAcb1-3Galb1-4GIcNAcb1-3Galb1-4GIcNAcb1- } \\
\text { 2Mana1-3)Manb1-4GIcNAcb1-4GlcNAcb-Sp12 }\end{array}$ & 148 & 42 & 28 \\
\hline 596 & $\begin{array}{l}\text { Neu5Aca2-6Galb1-4GIcNAcb1-3Galb1-4GIcNAcb1- } \\
\text { 3Galb1-4GIcNAcb1-2Mana1-6(Neu5Aca2-6Galb1- } \\
\text { 4GIcNAcb1-3Galb1-4GlcNAcb1-3Galb1-4GIcNAcb1- } \\
\text { 2Mana1-3)Manb1-4GlcNAcb1-4GlcNAcb-Sp12 }\end{array}$ & 143 & 46 & 32 \\
\hline 539 & $\begin{array}{l}\text { Galb1-4GIcNAcb1-3Galb1-4GIcNAcb1-3Galb1-4GlcNAcb1- } \\
\text { 2Mana1-6(Galb1-4GIcNAcb1-3Galb1-4GIcNAcb1-3Galb1- } \\
\text { 4GlcNAcb1-2Mana1-3)Manb1-4GlcNAcb1-4GlcNAcb-Sp12 }\end{array}$ & 121 & 14 & 12 \\
\hline (1) & $\begin{array}{l}\text { Galb1-3GIcNAcb1-3Galb1-4GIcNAcb1-6(Galb1- } \\
\text { 3GIcNAcb1-3Galb1-4GIcNAb1-2)Mana1-6(Galb1- } \\
\text { 3GIcNAcb1-3Galb1-4GIcNAcb1-2Mana1-3)Manb1- } \\
\text { 4GIcNAcb1-4(Fuca1-6)GlcNAcb-Sp24 }\end{array}$ & 115 & 34 & 29 \\
\hline 537 & $\begin{array}{l}\text { GIcNAcb1-3Galb1-4GlcNAcb1-3Galb1-4GlcNAcb1- } \\
\text { 2Mana1-6(GlcNAcb1-3Galb1-4GIcNAcb1-3Galb1- } \\
\text { 4GIcNAcb1-2Mana1-3)Manb1-4GIcNAcb1-4GlcNAcb-Sp12 }\end{array}$ & 113 & 2 & 1 \\
\hline 40 & (6S)Galb1-3(6S)GIcNAc-Sp0 & 108 & 17 & 16 \\
\hline & $4 \mathrm{~S}(3 \mathrm{~S})$ Galb1-4GIcNAcb-Sp0 & 106 & 37 & 35 \\
\hline
\end{tabular}


4Fig. 3 Graphical representation of P[3] VP8* (bat LZHP2 (up panel), human M2-102 (bottom panel)) VP8* at (A/C) $5 \mu \mathrm{g} / \mathrm{mL}$, and (B/D) $50 \mu \mathrm{g} / \mathrm{mL}$ binding to the array of 600 glycans. Relative Fluorescent Units (RFU) correspond to the strength of binding to individual glycans. Binding specificity is shown in mean relative fluorescence units (RFU) of binding to $\mathrm{n}=6$ replicates of each glycan printed on the array and $\%$ coefficient of variation $(\% \mathrm{CV})$. The highest and lowest point from each set of 6 replicates has been removed so the average is of 4 values. The strength of binding at two concentrations is shown. Data for the top 10 of the glycans bound with highest intensity are listed in each table.

sialic acid binding site was discontinuous in the $\mathrm{P}[3]$ bat VP8* model (Fig. 7B). The electrostatic potential was also different with positive charge in P[3] bat VP8* model and negative charge in P[3] RRV VP8* (Fig. 7C).

\section{Discussion}

Many rotavirus genotypes can infect different species and species-specific RV strains are frequently identified (Papp et al. 2013). The zoonotic potential has led to the increased burden of RV control and prevention (Doro et al. 2015). The glycan binding specificity of different virus strains are vital for understanding the host infection and tropism (Ramani et al. 2016). VP8*, located at the distal terminal of the VP4 spike, was involved in the glycan recognition and played an important role in the virus attachment

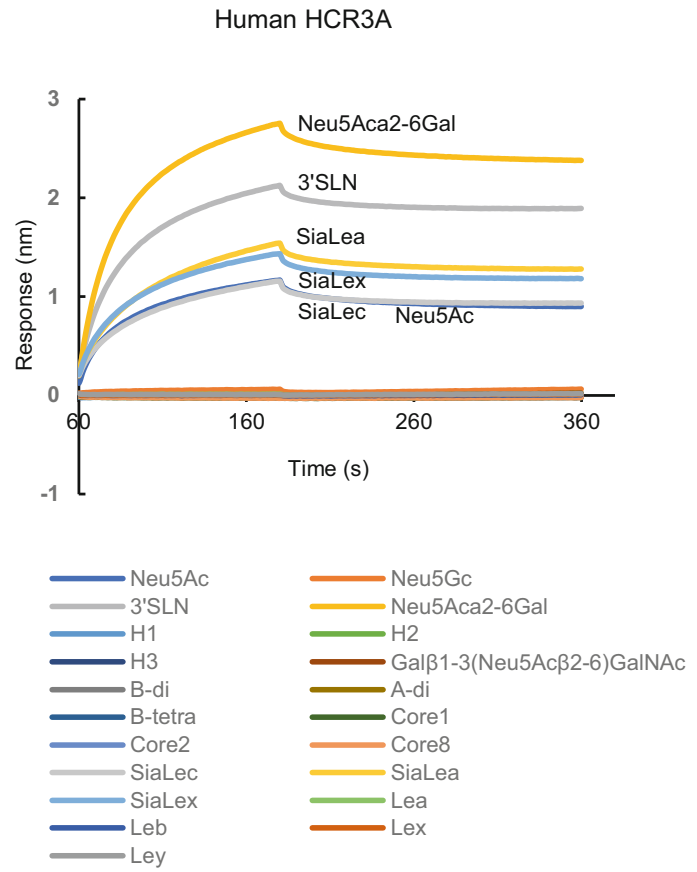

Fig. 4 Biolayer interometry (BLI) analysis. PAA-biotin labeled oligosaccharides, Neu5Ac, Neu5Gc, Neu5Ac $\alpha 2-3 \mathrm{Gal} \beta 1-4 \mathrm{GlcNA}$ (3'SLN), Neu5Ac $22-6 \mathrm{Gal}, \mathrm{H1}, \mathrm{H} 2, \mathrm{H} 3$, Neu5Ac $\beta 2-6(\mathrm{Gal} \beta 1-3) \mathrm{Gal}-$ NAc, B disaccharide, A disaccharide, B tetrasaccharide, core1, core2, core8, siaLea, siaLex, siaLec, lea, leb, lex, ley were loaded on the
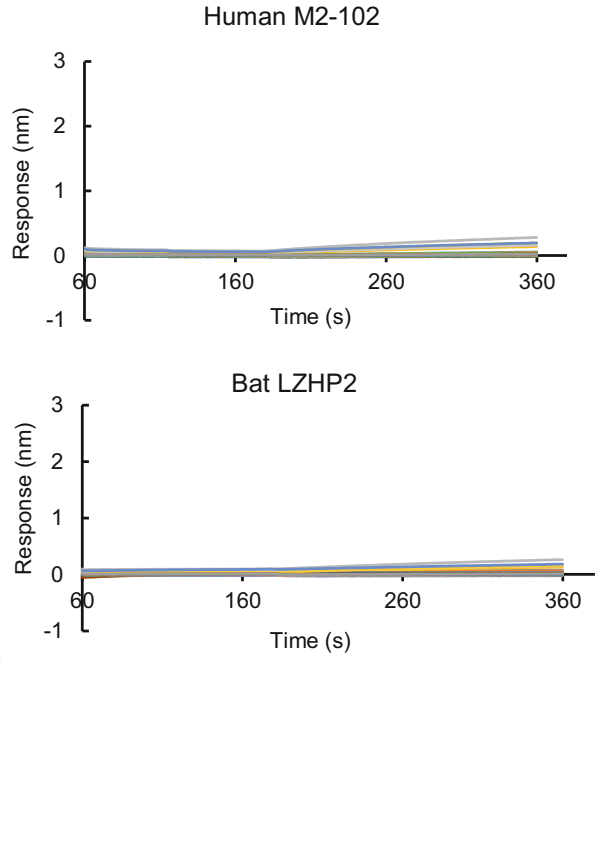

(Huang et al. 2012; Ramani et al. 2016). Bats are recognized as the reservoir of many viruses, including the lifethreatening Ebola virus, SARS, influenza virus. Rotaviruses in bats were identified by several studies (Esona et al. 2010; He et al. 2013, 2017). P[3] RVs are also found in cats/dogs and some feline/canine-like RVA strains are identified to infect humans sporadically (Tsugawa and Hoshino 2008). The glycan specificity and molecular mechanism of the cross-species transmission is important for understanding the virus prevalence. Here, we delineated the functional features of P[3] RV VP8*s of different species.

Bat LZHP2 P[3] VP8* showed no hemagglutination to all the erythrocytes tested, while other VP8* hemagglutinated the cells, indicating that bat LZHP2 P[3] VP8* probably do not interact with classical ligands that were recognized by Rhesus P[3] RV (Dormitzer et al. 2002a). Glycan binding assay verified that human HCR3A, 12,638, and dog RV198-95 P[3] VP8* bound to glycans with sialic acid while bat P[3] VP8* did not. Human M2-102 hemagglutinated the red blood cells, while showed no obvious binding to the glycans with sialic acid, providing more evidence that human M2-102 was originated from bat P[3] RVs. Human HCR3A and dog RV198-95 P[3] exhibited similar binding to both Neu5Aca2-3Gal and Neu5Aca2-6Gal, indicating that these P[3] RV bound sialic acid irrespective of the $\alpha 2-3$ or $\alpha 2-6$ linkage and

biosensor at $10 \mu \mathrm{g} / \mathrm{mL}$. Human HCR3A, M2-102, and bat LZHP2 $\mathrm{P}[3] \mathrm{VP}^{*}$ proteins were diluted at $10 \mu \mathrm{mol} / \mathrm{L}$ and applied to the association and dissociation procedures. The glycan binding data was analyzed by the Octet analyzing software. 


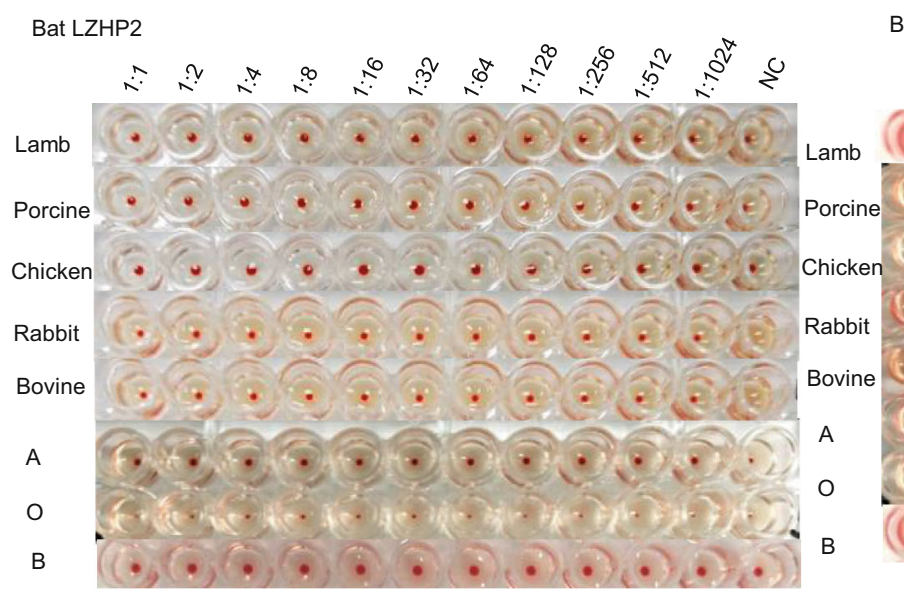

Bat LZHP2 C189Y mutant

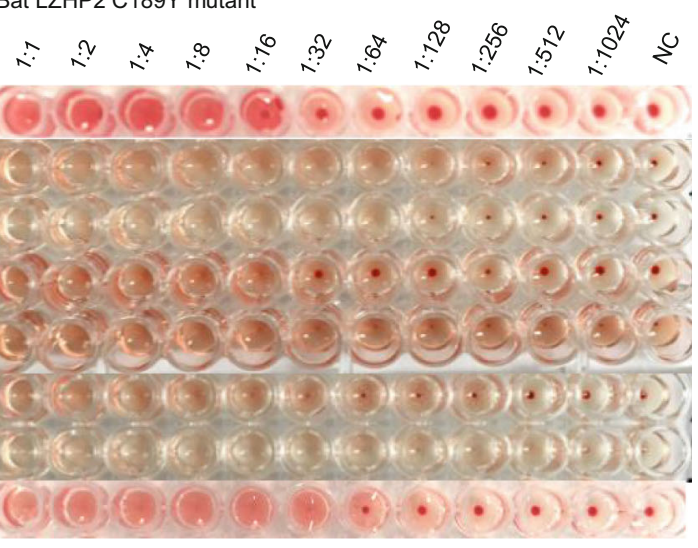

Human M2-102 Y189C mutant
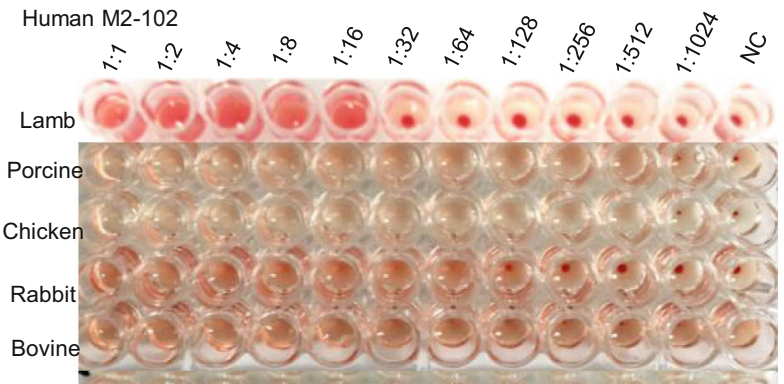

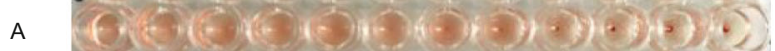

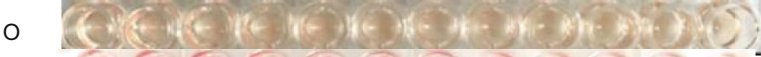

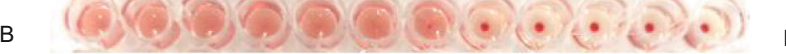
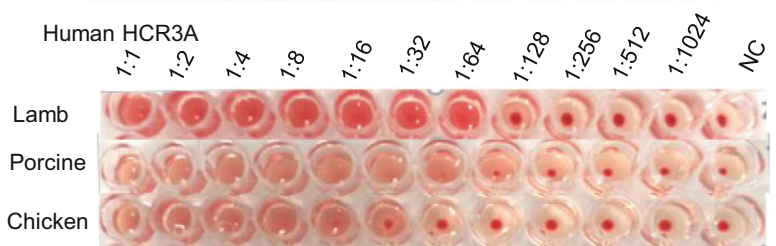

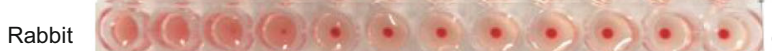

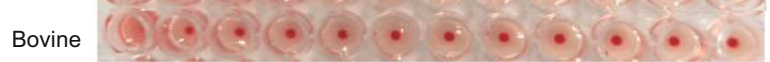
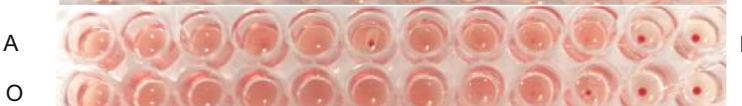

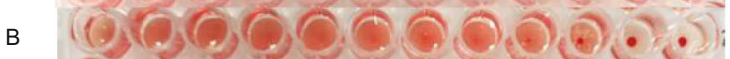
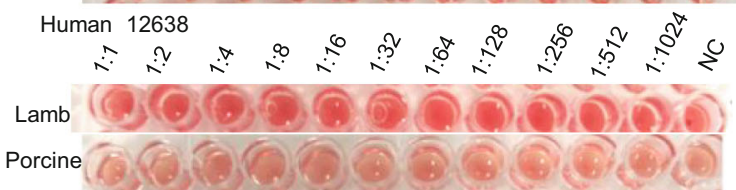

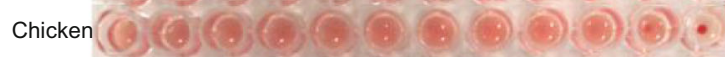

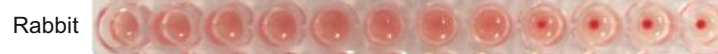

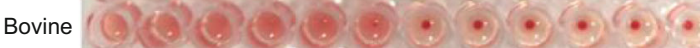

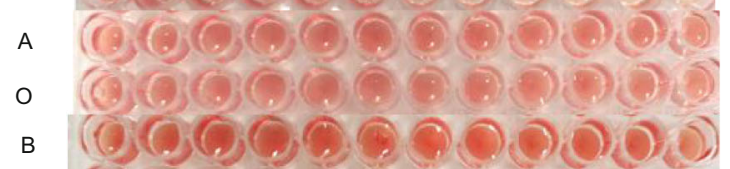

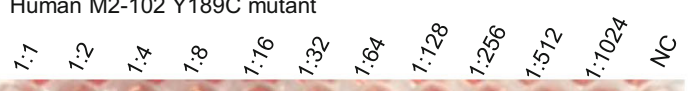

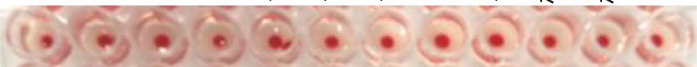

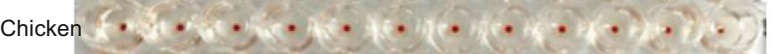

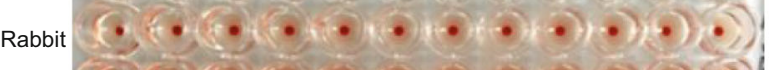

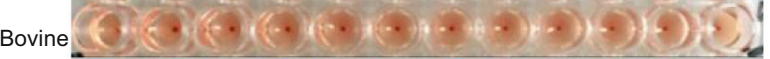

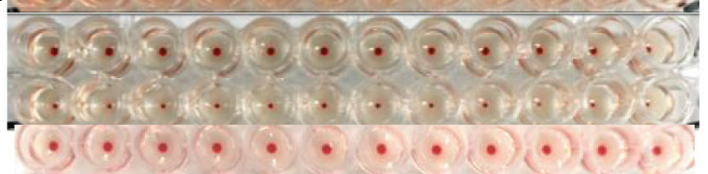

Human HCR3A Y189C mutant

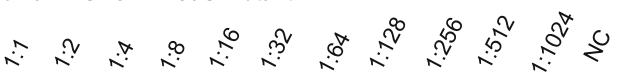
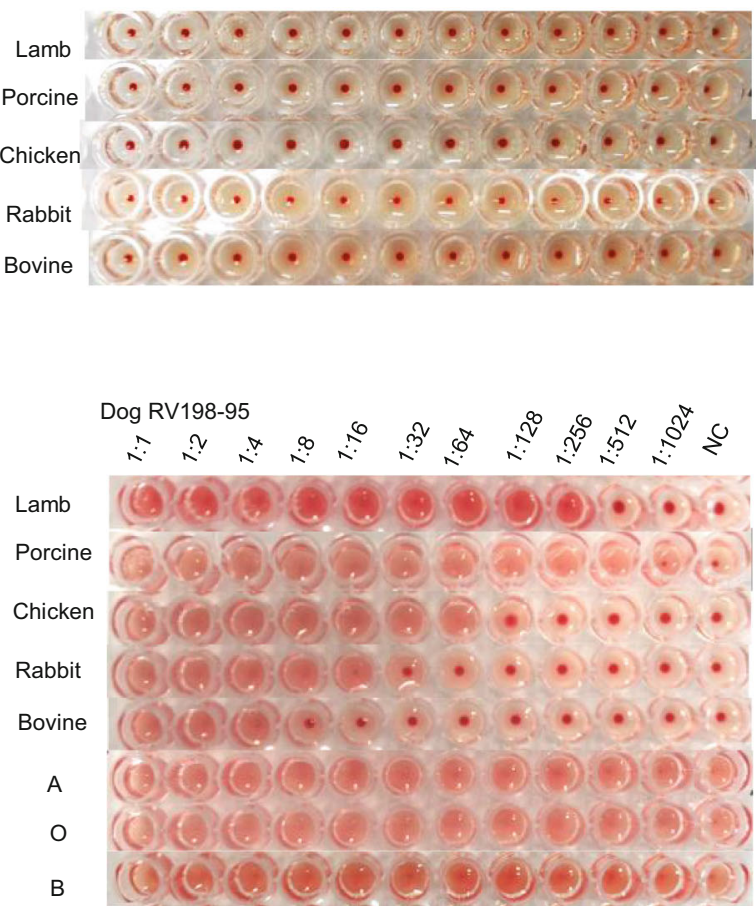

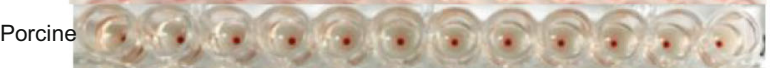

Fig. 5 The hemagglutination assay of P[3] RV VP8*s. Red blood cells of chicken, porcine, rabbit, bovine, human A, B, O were used in the assay. The protein at $2 \mathrm{mg} / \mathrm{mL}$ was diluted serially with PBS as shown. PBS buffer was used as the negative control (NC). 
Bat LZHP2 MASLIYRQLLTNSYSVDLSDEIQKIGSTKTQNVTVNPGPFAQTGYAPVNWGPGE INDSTTVEPVLDGPYQPTTFNPPVDY Human M2-102 MASLIYRQLLTNSYSVDLSDEIQKIGSTKTQNVTVNPGPFAQTGYAPVNWGPGETNDSTTVEPVLDGPYQPTTFNPPVDY Human 12638 MASFIYRQLLTNSYTVNLSDEIQEIGSTKTQNITINPGPFAQTGYAPVNWGPGETNDSTTIEPVLDGPYQPTSFNPPVGY Human HCR3A MASLIYRQLLTNSYTVNLSDEIQEIGSTKTQNITINPGPFAQTGYAPVNWGPGETNDSTTIEPVLDGPYQPTSFNPPVGY Dog RV198-95 MASLIYRQLLTNSYTANLSDEIQEIGSIKTQNTTINPGPFAQTGYAPVNWGPGETNDSTTIEPVLDGPYQPTSFNPPVGY

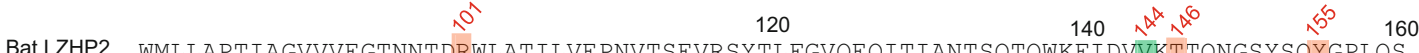

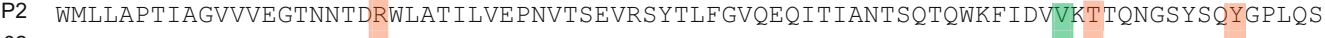
W2-102 WMLLAPTVAGVVVEGTNNTDRWLAT ILVEPNVTSEVRSYTLFGVQEQITIANTSQTQWKFIDVVKTAQSGSYSQYGPLQS Human 12638 WMLLSPTTAGVIVEGTNNTDRWLATILIEPNVTSQQRTYTIFGVQEQITVENTSQTQWRFVDVSKTTQNGSYSQYGPLLS Human HCR3A WMLLSPTVAGVIVEGTNNTDRWLATILIEPNVTSQQRTYTIFGVQEQITVENTSQTQWRFVDVSKTTQNGSYSQHGPLLS Dog RV198-95 WMLLSPTTAGVIVEGTNNTDRWLATILIEPNVTSQQRTYTIFGVQEQITVENTSQTQWRFVDVSKTTQNGSYSQYGPLLS

Bat LZHP2 $\begin{array}{cccc}180 & 1^{89} \wedge^{\wedge} & 200 & 220 \\ \text { SPKLYAVMKHNGKIYTYNGETPNATTGYCSTTNYDSVNMTAFCDFYI IPRAEESTCTEYINNGLPPIQNT }\end{array}$

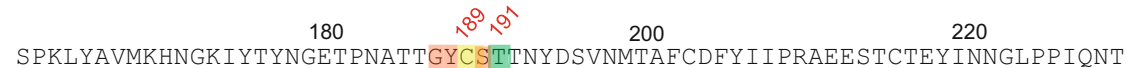
$\begin{array}{cccc}180 & 1^{89} \wedge^{\wedge} & 200 & 220 \\ \text { SPKLYAVMKHNGKIYTYNGETPNATTGYCSTTNYDSVNMTAFCDFYI IPRAEESTCTEYINNGLPPIQNT }\end{array}$ $\begin{array}{cccc}180 & 1^{89} \wedge^{\wedge} & 200 & 220 \\ \text { SPKLYAVMKHNGKIYTYNGETPNATTGYCSTTNYDSVNMTAFCDFYI IPRAEESTCTEYINNGLPPIQNT }\end{array}$

Human M2-102 Human 12638 TPKLYAVMKYGGRIHTYSGQTPNATTGYYSATNYDSVNMTTFCDFYIIPRSEESKCTEYINNGLPPIQNT Human HCR3A TPKLYAVMKYGGRIHTYSGQTPNATTGYYSATNYDSVNMTTFCDFYIIPRSEESKCTEYINNGLPPIQNT Dog RV198-95 TPKLYAVMKYGGRIHTYSGQTPNATTGYYSATNYDSVNMTTFCDFYIIPRSEESKCTEYINNGLPPIQNT

Fig. 6 VP8* protein sequences of different P[3] strains were aligned using DNAMAN. The residues involved in the ligand binding were colored red. The amino acids that are different between bat and human/dog were presented in green. H155 in human HCR3A VP8* was colored blue. Residue C189 was colored yellow. GeneBank numbers of the sequences are: bat LZHP2 (KX814943), human M2102 (KU597745), human HCR3A (EU708904), human 12,638 (LC340022), dog RV198-95 (HQ661137).
A
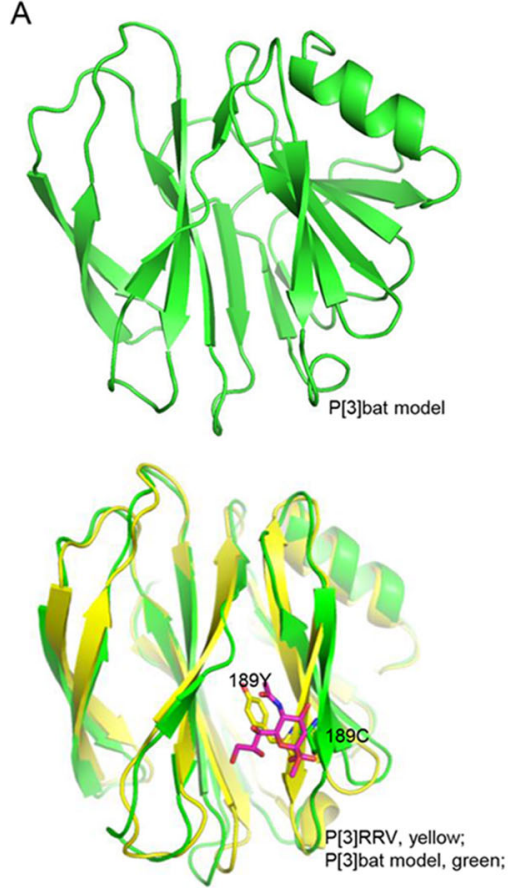

B
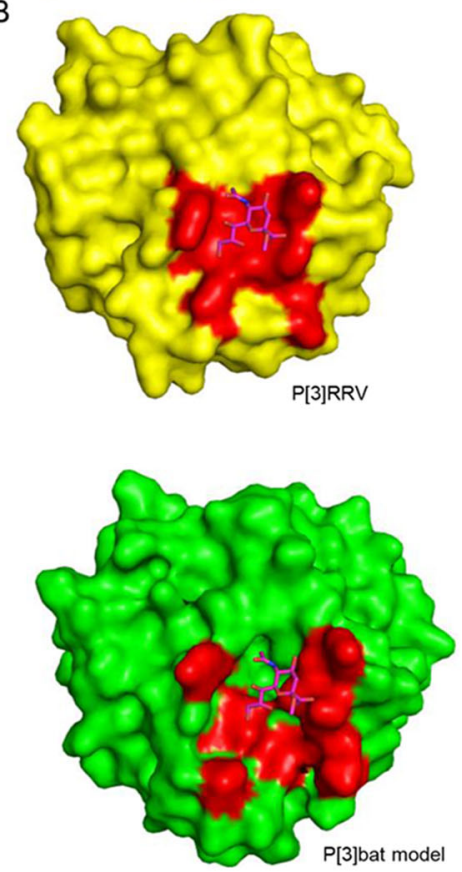

C
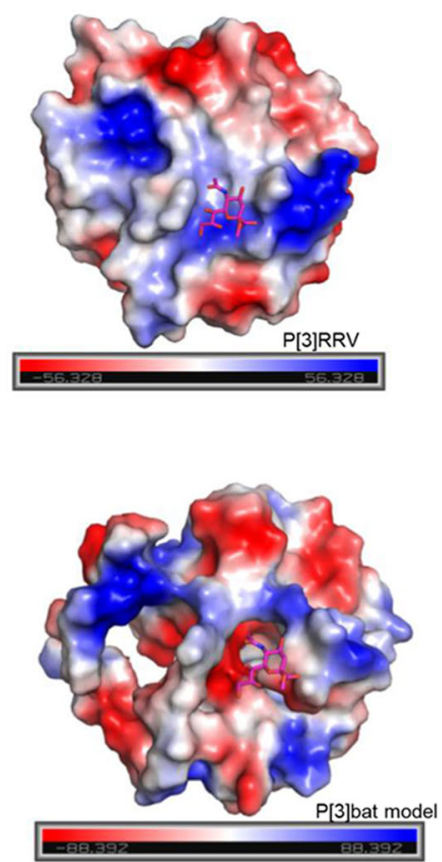

Fig. 7 Structural analysis of P[3] VP8*s. A Bat P[3] VP8* model was constructed using the SWISS-MODEL. Bat P[3] VP8* was superimposed to P[3] RRV VP8*s. VP8* was shown as cartoon. Residue 189 Y/C was emphasized using stick. Sialic acid was shown as stick. B P[3] RRV and P[3] bat VP8*s were shown as surface. The glycan binding site and putative glycan binding pocket were colored red. C The electrostatic potential presentation of $\mathrm{P}[3] \mathrm{RRV}$ and $\mathrm{P}[3]$ bat VP8*s. Red and blue indicate the positive and negative charge, respectively. 


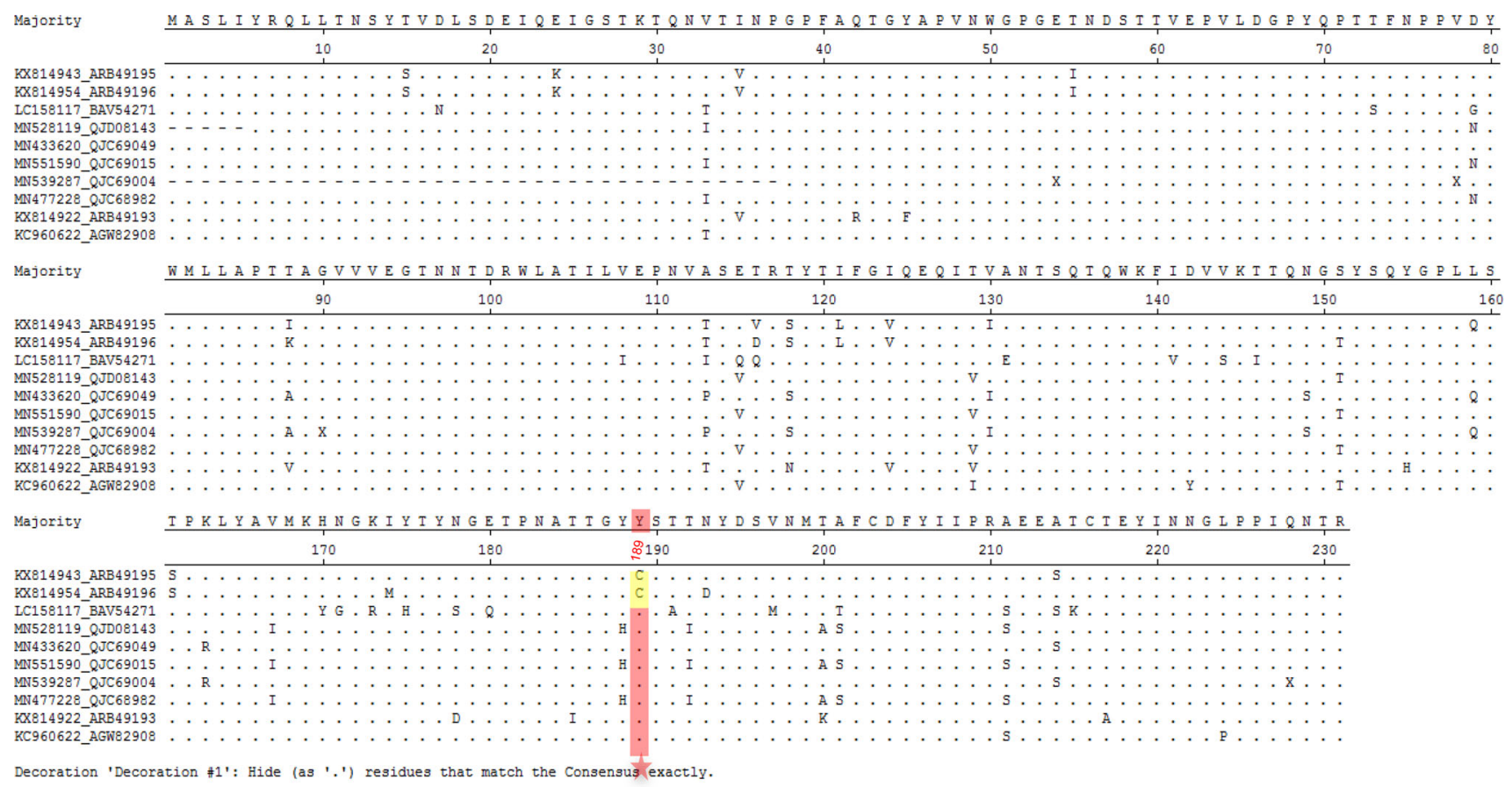

Fig. 8 Sequence alignment of ten bat P[3] RV VP8* protein sequences. The sequence alignment was done with MegAlign. Residue 189 was pointed with red star. 189C was colored yellow and $189 \mathrm{Y}$ was colored red. GeneBank numbers of the sequences are

possessed the potential of cross-species transmission. These results demonstrated that different P[3] VP8*s had various hemagglutination ability and glycan binding specificity. Bat P[3] VP8*s displayed no binding to sialic acid and probably could not infect human, while human/dog origin P[3] VP8*s bound sialic acid and could infect both human and animals.

Sequence alignment showed that several amino acids were different between bat LZHP2 and human RV VP8*s, including the residue 189. Bat LZHP2 C189Y mutant obtained the ability of hemagglutination while human $\mathrm{P}$ [3] Y189C mutant had no hemagglutination, implying that residue 189 was one of the key residues for the ligand recognition and the $\mathrm{C} 189 \mathrm{Y}$ alteration in M2-102 RV probably facilitate the sporadic bat-origin RV infection in human. Meanwhile, other amino acids, including residue 144, 155, and 191 may contribute to the different glycan binding capacity of $\mathrm{P}[3] \mathrm{VP} 8 *$.

The structural analysis revealed that the putative glycan binding site in bat P[3] VP8* model was quite different to that in the P[3] RRV VP8*, which partially explained that bat VP8* did not bind sialic acid glycans. These indicated that species barrier probably existed for bat LZHP2 P[3] RVs. Bat LZHP2 P[3] RV could not transmit to humans at present but may infect human sporadically with the C189Y alteration. Analysis of all the reported bat P[3] RV VP8* sequences showed that bat LZHP2 and YSSK5 (He et al. as following: LZHP2 (KX814943), YSSK5 (KX814954), LUS12-14 (LC158117), GKS-894 (MN528119), BB89-15 (433,620), GKS-94 (MN551590), BR89-60 (MN539287), GKS-954 (MN477228), BSTM70 (KX814922), MSLH14 (KC960622).

2017) possessed 189C, while other 8 strains contained 189Y (Fig. 8), implying that some bat P[3] RV strains may have the potential to infect human like the M2-102 strain. Therefore, the consistent surveillance of bat and animal $\mathrm{RVs}$ is needed.

Acknowledgements We acknowledge the participation of the ProteinGlycan Interaction Resource of the CFG (supporting grant R24 GM098791) and the National Center for Functional Glycomics (NCFG) at Beth Israel Deaconess Medical Center, Harvard Medical School (supporting grant P41 GM103694) for the analysis of samples by glycan microarray. We are grateful to professor Qi Shi and Jia Chen in the National Institute for Viral Disease Control and Prevention for their assistance in the BLI assay. This research was supported by grants from the National Natural Science Foundation of China (NSFC) (No. 21934005) and National Key Research and Development Program of China (2018YFC1200602).

Author contribution ZD, DL, and XS designed the experiments; MXW, DL, TM, and LP performed the protein expression and the glycan binding assay. MXW, MWW, QZ and HW carried out the hemagglutination assay. XS performed the biolayer interferometry assay and the structural analysis. XS and DL analyzed the data and constructed the figures. XS wrote the original draft of the manuscript. DL, ZD and XS revised the manuscript. All authors reviewed the manuscript and provided inputs.

\section{Compliance with EthicalStandards}

Conflict of interest All authors declare no potential conflict of interest. 
Animal and human rights statement All institutional and national guidelines for the care and use of laboratory animals were followed.

\section{References}

Banyai K, Kemenesi G, Budinski I, Foldes F, Zana B, Marton S, Varga-Kugler R, Oldal M, Kurucz K, Jakab F (2017) Candidate new rotavirus species in Schreiber's bats, Serbia. Infect Genet Evol 48:19-26

Blanchard H, Yu X, Coulson BS, von Itzstein M (2007) Insight into host cell carbohydrate-recognition by human and porcine rotavirus from crystal structures of the virion spike associated carbohydrate-binding domain $(\mathrm{VP} 8 *)$ J $\mathrm{Mol}$ Biol 367:1215-1226

Cholleti SR, Agravat S, Morris T, Saltz JH, Song X, Cummings RD, Smith DF (2012) Automated motif discovery from glycan array data. OMICS 16:497-512

Ciarlet M, Estes MK (1999) Human and most animal rotavirus strains do not require the presence of sialic acid on the cell surface for efficient infectivity. J Gen Virol 80:943-948

Dong H, Qian Y, Nong Y, Zhang Y, Mo Z, Li R (2016) Genomic characterization of an unusual human G3P[3] rotavirus with multiple cross-species reassortment. Bing Du Xue Bao 32:129-140

Dormitzer PR, Sun ZY, Blixt O, Paulson JC, Wagner G, Harrison SC (2002a) Specificity and affinity of sialic acid binding by the rhesus rotavirus VP8* core. J Virol 76:10512-10517

Dormitzer PR, Sun ZY, Wagner G, Harrison SC (2002b) The rhesus rotavirus VP4 sialic acid binding domain has a galectin fold with a novel carbohydrate binding site. EMBO J 21:885-897

Doro R, Farkas SL, Martella V, Banyai K (2015) Zoonotic transmission of rotavirus: surveillance and control. Expert Rev Anti Infect Ther 13:1337-1350

Esona MD, Mijatovic-Rustempasic S, Conrardy C, Tong S, Kuzmin IV, Agwanda B, Breiman RF, Banyai K, Niezgoda M, Rupprecht CE, Gentsch JR, Bowen MD (2010) Reassortant group A rotavirus from straw-colored fruit bat (Eidolon helvum). Emerg Infect Dis 16:1844-1852

Estes MK (2013) Greenberg HB rotaviruses. In: Knipe DM, Howley PM et al (eds) Fields virology, 6th edn. Wolters Kluwer Health/ Lippincott Williams \& Wilkins, Philadelphia, pp 1347-1401

Fiore L, Greenberg HB, Mackow ER (1991) The VP8 fragment of VP4 is the rhesus rotavirus hemagglutinin. Virology 181:553-563

He B, Huang X, Zhang F, Tan W, Matthijnssens J, Qin S, Xu L, Zhao Z, Yang L, Wang Q, Hu T, Bao X, Wu J, Tu C (2017) Group a rotaviruses in chinese bats: genetic composition, serology, and evidence for bat-to-human transmission and reassortment. J Virol 91.e02493

He B, Yang F, Yang W, Zhang Y, Feng Y, Zhou J, Xie J, Feng Y, Bao X, Guo H, Li Y, Xia L, Li N, Matthijnssens J, Zhang H, Tu C (2013) Characterization of a novel G3P[3] rotavirus isolated from a lesser horseshoe bat: a distant relative of feline/canine rotaviruses. J Virol 87:12357-12366

Huang P, Xia M, Tan M, Zhong W, Wei C, Wang L, Morrow A, Jiang $\mathrm{X}$ (2012) Spike protein VP8* of human rotavirus recognizes histo-blood group antigens in a type-specific manner. J Virol 86:4833-4843

Isa P, Arias CF, Lopez S (2006) Role of sialic acids in rotavirus infection. Glycoconj J 23:27-37

Komoto S, Tacharoenmuang R, Guntapong R, Upachai S, Singchai P, Ide T, Fukuda S, Hatazawa R, Sutthiwarakom K, Kongjorn S, Onvimala N, Luechakham T, Sriwanthana B, Murata T, Uppapong B, Taniguchi K (2020) Genomic characterization of a novel G3P[10] rotavirus strain from a diarrheic child in Thailand: Evidence for bat-to-human zoonotic transmission. Infect Genet Evol 87:104667

Ma X, Li DD, Sun XM, Guo YQ, Xiang JY, Wang WH, Zhang LX, Gu QJ, Duan ZJ (2015) Binding patterns of rotavirus genotypes $\mathrm{P}[4], \mathrm{P}[6]$, and $\mathrm{P}[8]$ in China with histo-blood group antigens. PLoS One 10:e134584

Matthijnssens J, Ciarlet M, McDonald SM, Attoui H, Banyai K, Brister JR, Buesa J, Esona MD, Estes MK, Gentsch JR, IturrizaGomara M, Johne R, Kirkwood CD, Martella V, Mertens PP, Nakagomi O, Parreno V, Rahman M, Ruggeri FM, Saif LJ, Santos N, Steyer A, Taniguchi K, Patton JT, Desselberger U, Van Ranst M (2011) Uniformity of rotavirus strain nomenclature proposed by the rotavirus classification working group (RCWG). Arch Virol 156:1397-1413

Nyaga MM, Tan Y, Seheri ML, Halpin RA, Akopov A, Stucker KM, Fedorova NB, Shrivastava S, Duncan Steele A, Mwenda JM, Pickett BE, Das SR, Jeffrey Mphahlele M (2018) Whole-genome sequencing and analyses identify high genetic heterogeneity, diversity and endemicity of rotavirus genotype P[6] strains circulating in Africa. Infect Genet Evol 63:79-88

Okitsu S, Hikita T, Thongprachum A, Khamrin P, Takanashi S, Hayakawa S, Maneekarn N, Ushijima H (2018) Detection and molecular characterization of two rare G8P[14] and G3P[3] rotavirus strains collected from children with acute gastroenteritis in Japan. Infect Genet Evol 62:95-108

Papp H, Laszlo B, Jakab F, Ganesh B, De Grazia S, Matthijnssens J, Ciarlet M, Martella V, Banyai K (2013) Review of group A rotavirus strains reported in swine and cattle. Vet Microbiol 165:190-199

Ramani S, Hu L, Venkataram Prasad BV, Estes MK (2016) Diversity in rotavirus-host glycan interactions: a "sweet" spectrum. Cell Mol Gastroenterol Hepatol 2:263-273

Sasaki M, Orba Y, Sasaki S, Gonzalez G, Ishii A, Hang'ombe BM, Mweene AS, Ito K, Sawa H (2016) Multi-reassortant G3P[3] group A rotavirus in a horseshoe bat in Zambia. J Gen Virol 97:2488-2493

Sun X, Dang L, Li D, Qi J, Wang M, Chai W, Zhang Q, Wang H, Bai R, Tan M, Duan Z (2020) Structural basis of glycan recognition in globally predominant human $\mathrm{p}[8]$ rotavirus. Virol Sin 35:156-170

Sun X, Li D, Qi J, Chai W, Wang L, Wang L, Peng R, Wang H, Zhang Q, Pang L, Kong X, Wang H, Jin M, Gao GF, Duan Z (2018) Glycan binding specificity and mechanism of human and porcine P[6]/P[19] rotavirus VP8*s. J Virol 92:e00538-18

Tsugawa T, Hoshino Y (2008) Whole genome sequence and phylogenetic analyses reveal human rotavirus $\mathrm{G} 3 \mathrm{P}[3]$ strains Ro1845 and HCR3A are examples of direct virion transmission of canine/feline rotaviruses to humans. Virology 380:344-353 